\title{
$\begin{array}{ll}\text { Research Square } & \text { Preprints are preliminary reports that have not undergone peer review. } \\ \text { They should not be considered conclusive, used to inform clinical practice, } & \text { or referenced by the media as validated information. }\end{array}$
}

\section{Transcriptomic Alterations Induced by Vemurafenib After Treatment of Melanoma: A Comprehensive Bioinformatics Analysis}

\section{Jiaheng Xie}

Jiangsu Province Hospital and Nanjing Medical University First Affiliated Hospital

https://orcid.org/0000-0002-4992-498X

\section{Yuan Cao}

The 4th Clinical Medical College of Nanjing Medical University: The Fourth School of Clinical Medicine

Zhechen Zhu

Jiangsu Province Hospital and Nanjing Medical University First Affiliated Hospital

\section{Shujie Ruan}

Jiangsu Province Hospital and Nanjing Medical University First Affiliated Hospital

\section{Ming Wang}

Jiangsu Province Hospital and Nanjing Medical University First Affiliated Hospital

Jingping Shi ( $\nabla$ jpshi2021@163.com )

Nanjing Medical University First Affiliated Hospital

Keywords:

Posted Date: May 19th, 2021

DOI: https://doi.org/10.21203/rs.3.rs-509411/v2

License: (c) (i) This work is licensed under a Creative Commons Attribution 4.0 International License.

Read Full License

Version of Record: A version of this preprint was published at Indian Journal of Pharmaceutical Sciences on January 1st, 2021. See the published version at https://doi.org/10.36468/pharmaceuticalsciences.spl.351. 


\section{Abstract}

The authors have requested that this preprint be removed from Research Square. 